\title{
Cost efficacy of sentinel lymph node biopsy in endometrial cancer patients
}

Christos Iavazzo $^{1}$, Victoria Psomiadou ${ }^{1}$, Alexandros Fotiou ${ }^{1}$, and Nikolaos Vrachnis ${ }^{2}$

${ }^{1}$ Metaxa Cancer Hospital of Piraeus

${ }^{2} 2$ 3rd Department of Obstetrics and Gynecology, National and Kapodistrian University of Athens Medical School, Attikon Hospital, 12462 Athens, Greece

February 14, 2022

\section{Hosted file}

title SLN.docx available at https://authorea.com/users/460350/articles/556387-cost-efficacyof-sentinel-lymph-node-biopsy-in-endometrial-cancer-patients

\section{Hosted file}

Cost efficacy of sentinel lymph node biopsy in endometrial cancer patients.docx available at https://authorea.com/users/460350/articles/556387-cost-efficacy-of-sentinel-lymph-nodebiopsy-in-endometrial-cancer-patients 